\title{
KARMAŞIK DALGACIK DÖNÜŞÜMÜ TABANLI YAPAY SIINİR AĞLARI İLE YÜZ ALGILAMA
}

\author{
${ }^{1}$ Gülden ELEYAN, ${ }^{2 Z i y a ~ T E L A T A R ~}$ \\ ${ }^{1}$ Elektrik-Elektronik Mühendisliği Bölümü, Avrasya Üniversitesi, Trabzon, Türkiye \\ ${ }^{2}$ Elektrik-Elektronik Mühendisliği Bölümü, Ankara Üniversitesi, Ankara, Türkiye \\ 1'gulden.eleyan@avrasya.edu.tr, 2telatar@ankara.edu.tr
}

(Geliş/Received: 08.02.2018; Kabul/Accepted in Revised Form: 27.08.2018)

ÖZ: Bu çalışmada yüz algılama için Gabor dalgacık dönüşümleri ve Çift Ağaç dalgacık dönüşümleri kullanılarak öznitelik çıkarımı yapılmıştır. Sınıflandırma basamağında ileri beslemeli yapay sinir ağları kullanılmıştır. Önerilen algoritmaların ilkinde, sinir ağlarını eğitmek için Çift Ağaç öznitelik vektörleri kullanılırken, ikincisinde sinir ağlarının eğitiminde Gabor öznitelik vektörleri kullanılmaktadır. Önerilen üçüncü algoritma ise ilk iki algoritmanın algı sonuçlarının OR mantık işlemi ile birleştirilmesinden oluşmaktadır. Sistemin başarımı yanlış algı oranının da hesaba katıldığ MIT+CMU, FRAV2D, BioID, BANCA veri tabanları üzerinde simülasyonlar gerçekleştirilmiştir. Gabor dalgacık vektörlerinin boyutları farklı oranlara indirgenerek işlem zamanı ve performans üzerindeki etkileri incelenmiştir.

Anahtar Kelimeler: Çift ağaç dalgacık dönüşümü, Gabor dalgacık dönüşümü, Sinir ağları, Yüz algılama

\section{Face Detection in Image Frames and Matching Through Face Database}

\begin{abstract}
In this study, feature extraction is performed using Gabor wavelet transforms and Dual Tree wavelet transforms for face detection. Artificial neural networks with feed forward are used in the classification step. In the first of the proposed algorithms, the Dual Tree feature extraction vectors are used to train the neural networks, while in the second proposed algorithm, the Gabor feature extraction vectors are used in the neural network training. The proposed third algorithm consists of combining the perception results of the first two algorithms with OR logic operation. The performance calculation of the system is realized with three metrics in which the wrong perception rate is included in the account. Simulations were performed on MIT + CMU, FRAV2D, BioID, BANCA databases. The dimensions of the Gabor wavelet vectors are reduced to different ratios and the effects on the processing time and performance are examined.
\end{abstract}

Key Words: Dual-Tree Wavelets Transform, Face Detection, Gabor Wavelets Transform, Neural Network.

\section{GİRIŞ (INTRODUCTION)}

Bir yüz algılama sistemi görüntünün öznitelik dizisini ayıran, bu öznitelik dizisini veri tabanındaki diğer öznitelik dizileriyle karşılaştıran ve bu karşılaştırma sonucuna göre karar veren bir yapıya sahiptir. Altı birimden oluşan sistem içeriğinde: veri edinim birimi, alt örnekleme birimi, önişleme birimi, öznitelik çıkarım birimi, sınıflandırma birimi ve çözümleme birimi yer almaktadır.

Veri edinim biriminde bir görüntünün ham bilgisi, uygun bir kamera veya tarayıcı ile elde edilmektedir. Kazanç birimi, insan makine ara yüzünü tanımlar. Bundan dolayı, yüz algılama sisteminin performansı için çok önemlidir. Kullanılan kameranın teknik özellikleri de edinilen veri kalitesi 
açısından çok önemlidir. Öznitelik çıkarım biriminde, ön işlemeden sonra yüze ait özelikleri ifade eden öznitelikler çıkarılır. Örneğin, bazı yüz algılama sistemlerinde bir yüz görüntüsündeki gözler, burun ve ağız arasındaki mesafe ve konum öznitelik çıkarım birimi ile belirlenir. Eğitim sırasında, bu öznitelik dizileri veri tabanında saklanır ve şablon olarak adlandırılır. Yüz şablonu tek bir görüntüden de seçilebilir, birden çok görüntü işlenerek de oluşturulabilir. Genellikle yüz algılama sistemleri birden çok şablon ile eğitilir, yapay olarak orijinal yüz görüntüsünden oluşturulur. Sınıflandırma biriminde karşılaştırma sonuçları oluşturmak için depolanmış şablonlar ile çıkarım yapılmış öznitelikler karşılaştırılır. Yüz tabanlı biyometrik bir sistemde, şablon dizileri ve test görüntüsü arasındaki en küçük uzaklık tespit edilir ve benzerlik sonuçları kaydedilir. Çözümleme (Arbitration) biriminde farklı boyutlardaki görüntülerin benzerlik sonuçları birleştirilir daha sonra yanlış olan algılamalar silinir.

Yüz algılama ve izleme için birçok yaklaşım ve algoritma önerilmiştir. Genel olarak yüz algılama yöntemleri dört kategoriye ayrılmıştır: Bilgi tabanlı yöntemler, Öznitelik tabanlı yöntemler, Şablon eşleme yöntemleri, Görüntü tabanlı yöntemler.

Bilgi tabanlı yöntemler yüze ait bilgilerden elde edilen önceden tanımlanmış kurallara dayanarak geliştirilmiştir. Örneğin, bir görüntüdeki yüz genellikle birbirine simetrik şekilde duran gözler, bir burun ve bir ağız olarak görünür. Öznitelikler arasındaki ilgili mesafe ve konum aralarındaki ilişkiyi ifade eder. Test edilecek görüntüdeki yüz olma ihtimali olan bölge, sökonusu kodlanmış kurallara göre tespit edilir. Yang ve diğ. (1994) bu yöntem ile görüntülerde yüz tespiti yapmışlardır.

İnsan gözü, yüzleri farklı pozlar ve farklı aydınlanma koşullarında kolayca algılayabilir. Tüm bu farklı koşulların yanında değişmeyen nitelikler de olmalıdır. Bazı yöntemler, ilk olarak kenar algılayıcılar ile kaş, göz, burun, ağız, ve saç çizgisini algılar ve daha sonra yüzü bularak teyit eder. Ten rengi de özellik olarak kullanılabilir. Çıkarım yapılmış özniteliklere bağlı olarak, aralarındaki ilişkiyi tanımlamak ve yüzün varlı̆̆ını kanıtlamak için bir istatistiksel model kurulur. Öznitelik tabanlı algoritmalarda karşılaşılan bir problem görüntü özniteliklerinin aydınlanma, gürültü ve kapanmalara bağlı olarak bozulmaya uğramalarıdır. Özniteliklerin sınırları gölgelerin güçlü kenarlar oluşturmasına bağlı olarak belirsizleşir. Bu durum da algoritmaların yetersiz kalmasına sebep olur.

Şablon eşleme yöntemlerinde, standart bir ön cephe yüz şablonu önceden tanımlanır veya bir fonksiyon ile ifade edilir. Bir test görüntüsünün ilinti değerleri, standart bir şablon üzerinde; yüz hatları, göz, burun ve ağız için birbirinden bağımsız olarak hesaplanır. İlinti değerlerine dayanarak yüz olup olmadığına karar verilir. Bu yöntemin uygulaması kolaydır. Fakat buna rağmen ölçek, poz, ve şekil değişikliklerine bağlı olarak algılama başarısı düşmektedir.

Çoklu çözünürlük, çoklu ölçek, alt şablonlar ve biçim değiştirebilen şablonların kullanılması ile değişmeyen ölçeklerin elde edilip ön cephe yüzlerinin şekil şablonuna dayalı bir yöntem ile bulunmasına dayalı önerdiği algoritmaya göre, test edilecek görüntülerden süzgeçler ile detaylar çıkarılmaktadır ve yüzün yerleştirilmesinden sonra yüz ile ilgili özniteliklerin yerleştirilmesi için birkaç kez uygulanmaktadır (Türkeç 2007).

Görüntü tabanlı yöntemlerde yüz görüntülerinin ve yüz olmayan görüntülerin özniteliklerinin bulunması için makine öğrenimi ve istatistiksel analiz teknikleri kullanılır. Tsai ve diğ. (2006) Özyüzlerin (Turk ve Petland 1991) yüz algılama için kullanıldığını bildirmişlerdir. Özyüz uzayı, sınıflandırma için sinir ağlarının uygulanmasından önce öznitelik çıkarımı için kullanılmıştır. Rowley (1998)'nin yüz algılama konusu için yapay sinir ağlarını kullandığı çalışması, diğer araştırmacılar için bir referans olmuştur.

Destek Vektör Makinaları, (SWM) yüz algılama için kullanılmış bir diğer yöntemdir (Shah 2012, Ratsch ve diğ., 2004). Gerçek zamanlı çalışan SVM tabanlı bir yüz tanıma sistemi, kullanıcının yüz özelliklerini kullanmaktadır (Hui Lin ve diğ., 2016). Schneiderman ve Kanade (2000) 3B nesne algılama için kullanılan istatistiksel bir yöntem önermişlerdir. Liu (2003) Bayes ayrıştırma özniteliklerinin kullanıldığı bir yöntem önermiştir.

Yüz algılama konusunda dalgacıkların (wavelets) kullanıldığı pekçok çalışma mevcuttur. Huang ve diğ. (2005) gabor dalgacıklar kullanırken, ( Seok ve diğ., 2006) heterojen yüz tanıma için tek saklı katmana sahip Gabor dalgacıkları kullanmışlardır. Nanni ve Lumini (2007) radyal tabanlı fonksiyonlar 
(radial basis function) ve destek vektör makineleri (SVM) ile yüz algılama gerçekleştirmişlerdir. (Froba ve Ernest 2004)'de ise Geliştirilmiş Census Dönüşümü (GCD) kullannılmaktadır.

\section{MATERYAL VE YÖNTEM (MATERIAL and METHOD)}

$\mathrm{Bu}$ bölümde, önerilen yöntemler ve kullanılan algoritma detayları ile anlatılarak eğitim veritabanının hazırlanış şekli ile ilgili bilgi verilmiştir. Önişleme basamağında, algoritmanın çalışma süresini kısaltan öntarama işlemi gerçekleştirilmiştir. Yüz olma olasılığının yüksek olduğu alanların seçilmesi ve test görüntüsünün geri kalan kısımlarının yok sayılması esasına dayanan bu işlemden sonra Gabor ve Çift Ağaç karmaşık dalgacıklar öznitelik vektörleri çıkarılmış ve sınıflandırma için bu öznitelikler yapay sinir ağlarının girişine beslenmiştir.

\section{Gabor Dalgacık Dönüşümü (Gabor Wavelet Transform)}

Gabor dalgacıkları (GWT), istenilen her yönde mükemmel seçiciliğe sahip olacak şekilde ayarlanabilir. Aynı yönde sıralanmış özelliklere karşı güçlü cevap verirken diğer yönlere karşı cevabı zayıftır. Kayma ve dönmelere karşı değişmeme özelliği, başarılı olmalarında önemli bir rol oynamaktadır. Yüz görüntülerinde, yerel özelliklerin doğru ve eksiksiz olarak elde edilmesi için uzamsal frekans analizi yapılması gereklidir. Gabor fonksiyonları, uzamsal ayrışma ve frekans ayrışması arasında en iyi şekilde denge kurulmasını sağlar.
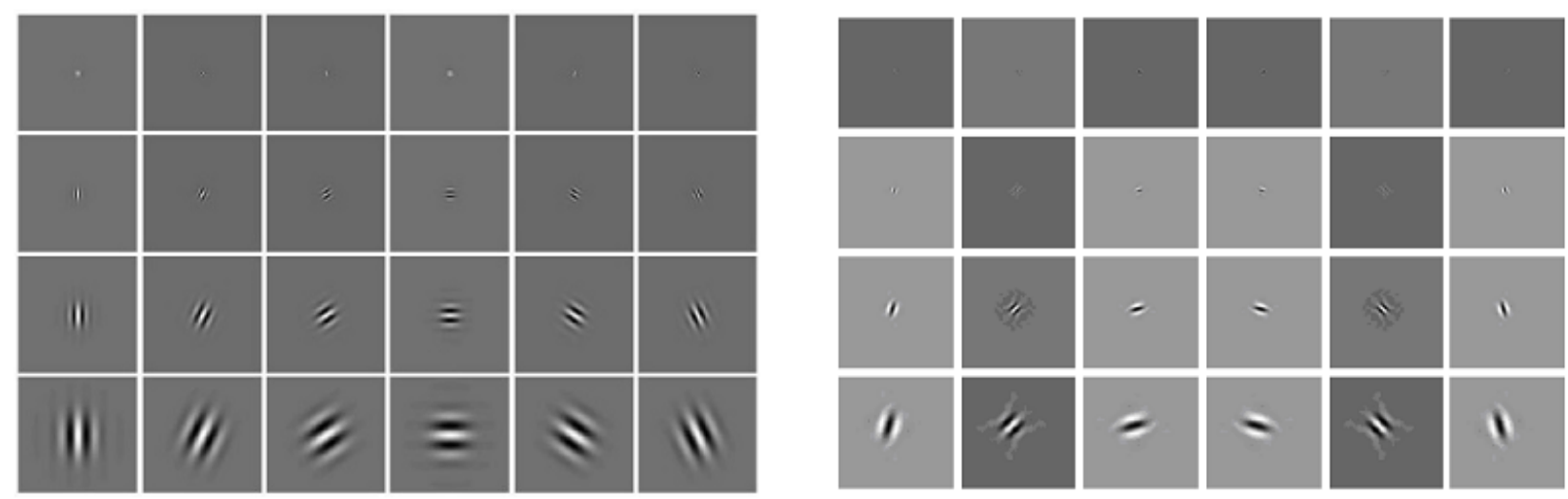

Şekil 1. 4 düzeyde ve 6 yöndeki Gabor (Solda) ve Çift Ağaç(Sağda) karmaşık dalgacıkların gerçel kısmı Figure 1. 4 scales and 6 directions of the real part of Gabor wavelets (left) and the dual-tree complex wavelets (right)

Şekil 1'de Gabor dalgacıklarının 4 ölçek ve 6 yönde sırasıyla gerçel kısmı ve büyüklüğü görülmektedir. Gabor dalgacıklarının en uygun frekans-uzay yerleşimi özelliği sayesinde, lokal görüntü alanından maksimum miktarda bilginin ayrıştırılması sağlanır. Bu özellik, yüz algılama ve tanıma uygulamalarında Gabor dalgacıklarını yüz ifade değişikliklerine karşı gürbüz kılar. Buna ek olarak, Gabor dalgacıkları DC bileşenleri olmadığı için görüntünün aydınlanma değişikliklerine karşı değişmezdir. Bu avantajlara rağmen, hesap yükünün ve hafıza gereksiniminin fazla olması gibi önemli dezavantajlara sahiptir (Eleyan ve diğ., 2009,). Gabor dalgacık özniteliklerini büyük ölçüde sergileyen ve hesaplama karmaşıklığı ve hafıza ihtiyacı daha az olan alternatif dönüşüm yöntemleri kullanılması tercih edilmektedir. Bu çerçevede karmaşık dalgacık dönüşümü (CWT) başarılı bir alternatif sunmaktadır.

Şekil 2.b ve 2.c'de Şekil 2.a'daki Gabor dalgacık dönüşümlü yüz görüntüsünün büyüklüğü ve gerçel kısmı görülmektedir. 


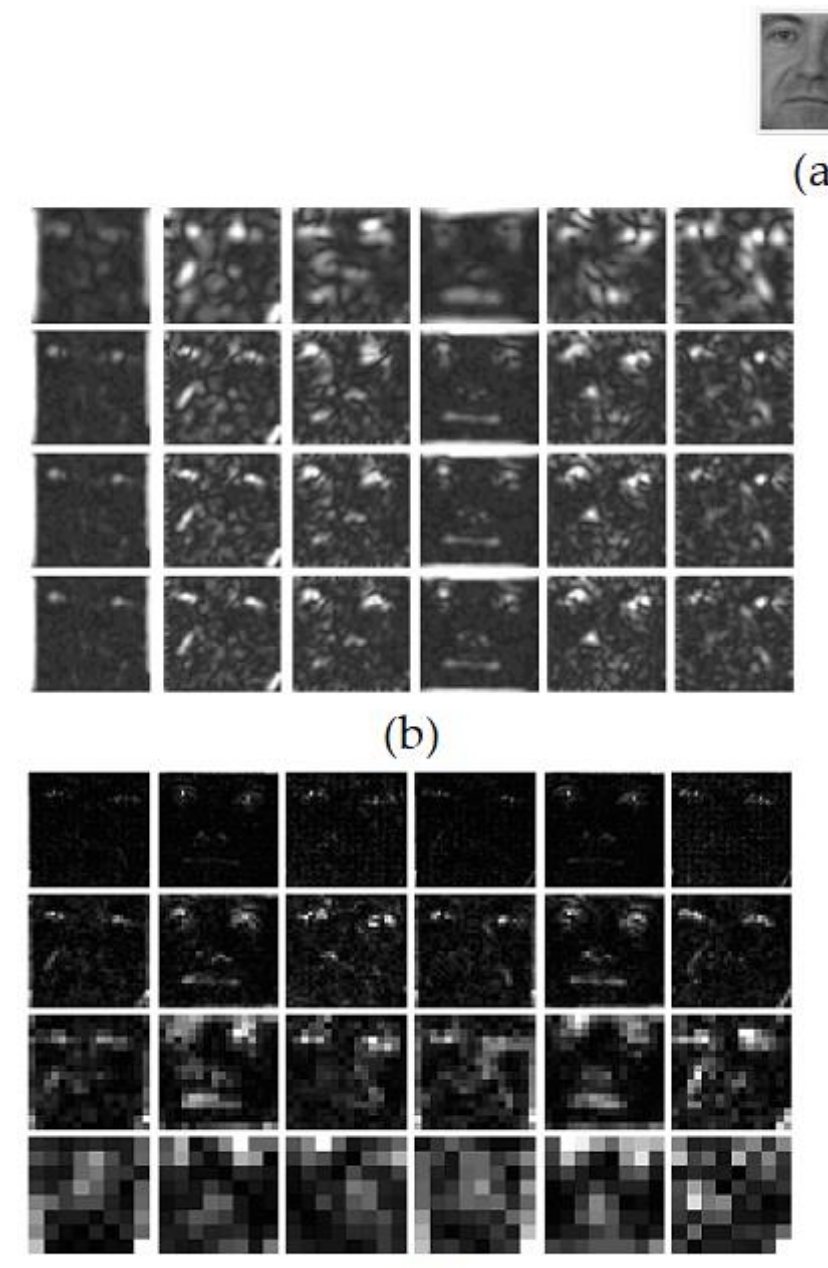

(d)

(a)

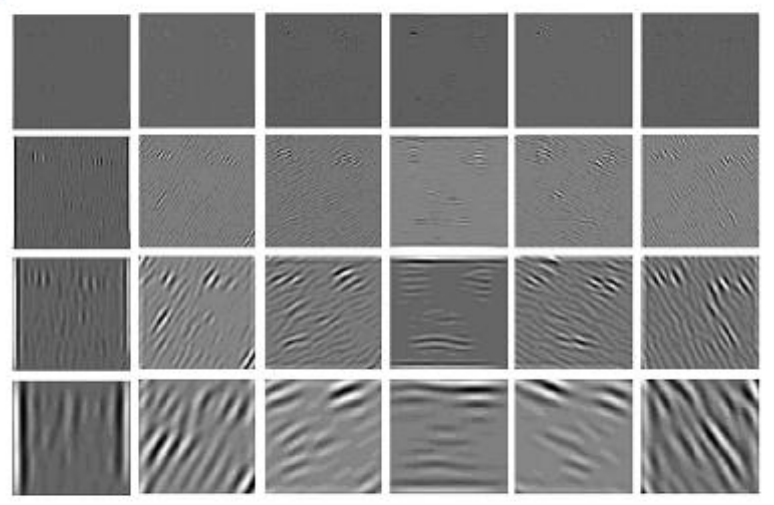

(c)

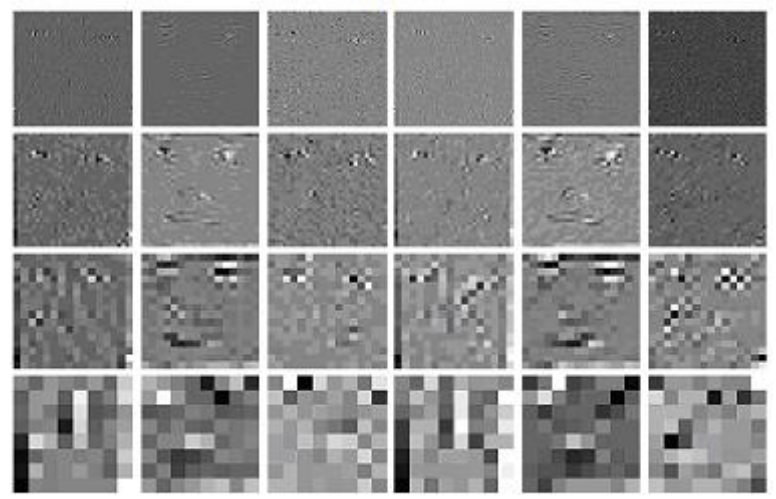

(e)

Şekil 2. (a) Yüz görüntüsü (b) Gabor dalgacık dönüşümünün büyüklüğü (c) Gabor dalgacık dönüşümün gerçel kısmı (d) Çift Ağaç dalgacık dönüşümünün büyüklüğü (e) Çift Ağaç dalgacık dönüşümün gerçel kısmı.

Figure 2. (a) Face image (b) The magnitude of Gabor wavelet transform (c) The real part of Gabor wavelet transform (d) The magnitude of dualtree wavelet transform (e) The real part of Dual-tree wavelet transform

\section{Çift Ağaç Karmaşık Dalgacık Dönüşümü (Dual-Tree Complex Wavelet Transform)}

Karmaşık dalgacıkların kayma ve düzlemdeki dönmelere karşı değişmezlik özelliği sayesinde, görüntünün çoklu ölçekli tanımlanması mümkündür. Gabor dalgacıklar gibi karmaşık dalgacıklar da, aydınlanma ve yüz ifadesi değişikliklerine karşı hassas değillerdir. Bunun yanısıra karmaşık dalgacık dönüşümünün hesap yükü daha azdır. Gabor dalgacıklarının bir önceki bölümde sözedilen olumsuzluklarına karşı Çift ağaç karmaşık dalgacık dönüşümü (DT-CWT) daha iyi sonuçlar verebilen yöntemlerden biridir (Kingsbury 2003). İki dalgacık ağacı, gerçel süzgeçler ile dalgacık yapısındaki yaklaşık Hilbert çiftleri ile paralel olacak şekilde geliştirilmiştir. Hilbert dönüşüm çifti oluşturmanın yolu, yarı örnekleme gecikme şartının sağlanmasıdır. Elde edilen karmaşık dalgacık, (tek taraflı) frekans uzayında yaklaşık olarak analitiktir. Karmaşık dalgacık dönüşümü, artı ve eksi frekansları ayırabilmektedir ve farklı yönlerde olan $( \pm 15, \pm 45$ ve \pm 75$)$ altı adet altbant oluşturmaktadır. Fakat, her açının elde edilebileceği Gabor modelinden farklı olarak bu yönler sabittir. 


\section{Yapay Sinir Ağları (Artificial Neural Networks)}

Yapay sinir ağları (YSA)'nın işleyişindeki paralellik ve yüksek hesaplama hızı ile diğer geleneksel sınıflandırıcılara ve karar verme sistemlerine göre oldukça etkindir. Eğitilebilen YSA için pekçok uygulama örneği mevcuttur. Bunlardan bazıları: Sınır çıkarımı, görüntü işleme, görüntü süzgeçleme'den oluşan önişleme, öznitelik çıkarımı (Acciani ve diğ., 2003), yüz tanıma ve sınıflandırma (Eleyan ve Demirel 2007), koroner kalp hastalı̆̆1 riski tahmin (Kim ve Kang 2017), prosess kontrol sistemleri (Sharma ve diğ., 2016), yol durumu tahmini (Hongxia 2007) ve Turizm talebinin tahmini (Karahan 2015).

\section{Eğitim ve Test Veri Setlerinin Oluşturulması (Creation of Training and Test Data Sets)}

Yapay sinir ağının eğitimi için 20×20 ölçülerinde 1000 yüz görüntüsü ve 1000 yüz olmayan görüntü kullanılmıştır. FERET ve ORL veritabanlarından 1000 yüz görüntüsü alınmıştır. Her iki veritabanındaki tüm yüzler 20×20 piksel'e yeniden boyutlandırılmıştır. FERET veriabanından 600 adet ön cephe görüntüsü seçilmiştir. Her birinde 3 görüntü olan 200 kişi için (ba, bj, bk) görüntü kodlarından oluşturulmuştur. Bu yüz görüntüleri seçilirken değişik aydınlanma koşulları (bk) ve farklı yüz ifadeleri (bj) içeren resimler tercih edilmiştir. Her yüz görüntüsü " 0 " ortalama değerine ve tek bir varyans değerine normalize edilir (Liu ve Wechsler 2003). ORL veritabanından gri ölçeklendirilmiş 400 görüntü (112×92 pixel) kullanılmıştır. Bu görüntüler, 40 kişinin iki yıl içinde çekilen farklı mimik ve farklı yüz detaylarından oluşan 10 farklı görüntüsüdür. Şekil 3’de veritabanlarından alınmış örnek görüntüler görülmektedir.
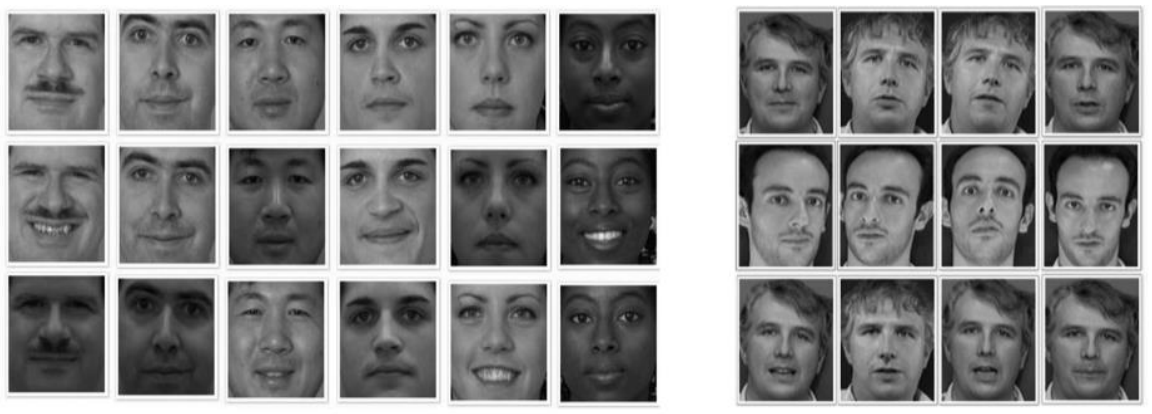

Şekil 3. Eğitim veritabanında kullanılan FERET(solda) ve ORL(sağda) veritabanlarından örnekler Figure 3. Examples from the FERET (left) and ORL (right) images used in the training database)

Eğitim setindeki her bir yüz görüntüsü için, farklı açılar (-20 derece ile +20 derece arası) ile döndürülerek hazırlanmış 10 farklı versiyonu oluşturulmuştur. Eğitim setinde kullanılmış bir yüzün 10 farklı versiyonu Şekil 4'de görülmektedir.
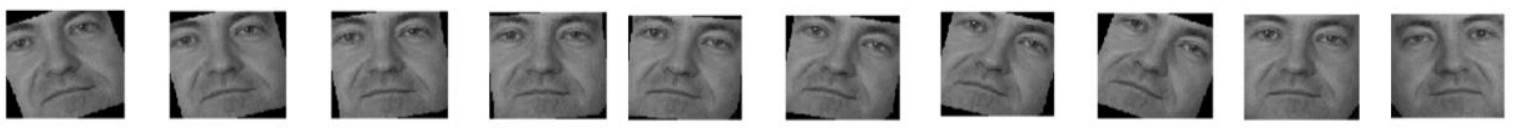

Şekil 4. Bir yüz görüntüsünün farklı dönme açları kullanılarak hazırlanmış 10 farklı görüntüsü: ( $-20^{\circ}$, $\left.15^{\circ},-10^{\circ},-5^{\circ}, 0^{\circ}, 5^{\circ}, 10^{\circ}, 15^{\circ}, 20^{\circ}\right)$ ve bir görüntünün yansıması

Figure 4.10 different generated tmages of a face image using different rotation angles: : $\left(-20^{\circ},-15^{\circ},-10^{\circ},-5^{\circ}, 0^{\circ}, 5^{\circ}, 10^{\circ}, 15^{\circ}, 20^{\circ}\right)$ and one image reflection

Yüz olmayan görüntülerin eğitim veritabanı (Training database for non-face images)

Yüz olmayan görüntülerden oluşan veritabanı 1000 nesneyi içermektedir. Bu görüntüler, büyük resimlerden, rastgele küçük parçaların kesilmesiyle oluşturulmuştur. Orijinal görüntülerin rastgele kısımlarından kesilmiş alt görüntüler Şekil 5'te görülmektedir. 


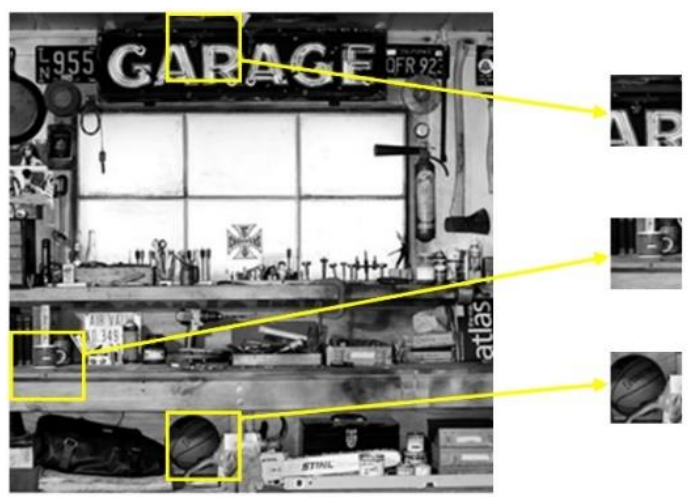

Şekil 5. Orijinal görüntülerden kırpılmış yüz olmayan görüntüler Figure 5. Cropped non-face images from original images

\section{Öznitelik Çıkarım Basamağı (Feature Extraction Step)}

Öznitelik çıkarımı için kullanılan yöntemler, Gabor dalgacıklar ve Çift Ağaçkarmaşık dalgacıklarıdır. Burada, görüntüye ait tüm verinin kullanılması yerine, belli başlı öznitelikleri kullanılmaktadır. Her iki yaklaşım için, yüz görüntülerinin çoklu ölçekli parçalanmaları 4 ölçek ve 6 yönde gerçekleştirilmiştir. Gabor dalgacık dönüşümünün ve Çift ağaç karmaşıł dalgacık dönüşümünün $X$ öznitelik vektörleri, çoklu ölçekli gösterim sonuçlarının ardarda eklenmesiyle (concatination) oluşmuştur. Verilen bir görüntü $\Gamma(x, y)$ ve $\psi_{s, d}(x, y)$ dalgacığı, "s" ölçek ve " $d$ " yön'ü göstermek üzere $X$ vektörü eşitlik 1 'deki gibi ifade edilebilir.

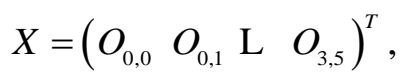

$O_{s, d}(x, y)=\Gamma(x, y) * \psi_{s, d}(x, y)$ ve $O_{s, d}(s=0, \ldots, 3, d=0,1, \ldots, 5)$ olmak üzere, $X O_{s, d}(x, y)$ 'nin satırlarının veya sütunlarının arka arkaya eklenmesiyle oluşturulmuştur. Burada * ve $T$ sirasıyla katlama ve transpozu ifade etmektedir. Şekil 6'da bir vektörü oluşturan yüz görüntüsü örneği görülmektedir.

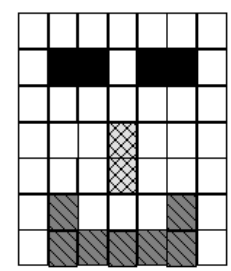

(a)

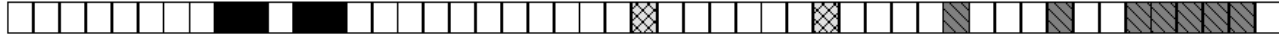

(b)

Şekil 6. Yüz görüntüsünün çoklu ölçekli gösterim sonuçlarının ardarda eklenmesi, (a) yüz görüntüsü (b) yüz öznitelik vektörü

Figure 6. Concatenation of multi-scale display results of face image, (a) face image (b) face feature vector

Her iki yöntemin öznitelik vektörlerinin uzunluğu farklılık göstermektedir. Gabor dalgacıklı çıkış görüntüsü, 4 ölçeğin herbirinde aynı boyutta olurken, Çift ağaç dalgacıklı çıkış görüntüleri, bir üst ölçekteki çıkış görüntüsünün boyutunun yarısına sahip olmaktadır.

\section{Yapay Sinir Ağlarının Eğitimi (Training of the artificial neural network)}

Giriş bölümünde kısaca değinildiği üzere, yüz algılama işleminin en önemli basamaklarından biri Sınıflandırma'dır. Bu çalışmada, sınıflandırma için Geriye Yayılım (back propagation) öğrenme algoritmasıyla birlikte İleri Beslemeli (feed forward) Yapay Sinir Ağları kullanılmıştır. Şekil 7'de YSA'nın eğitim safhası görülmektedir. 


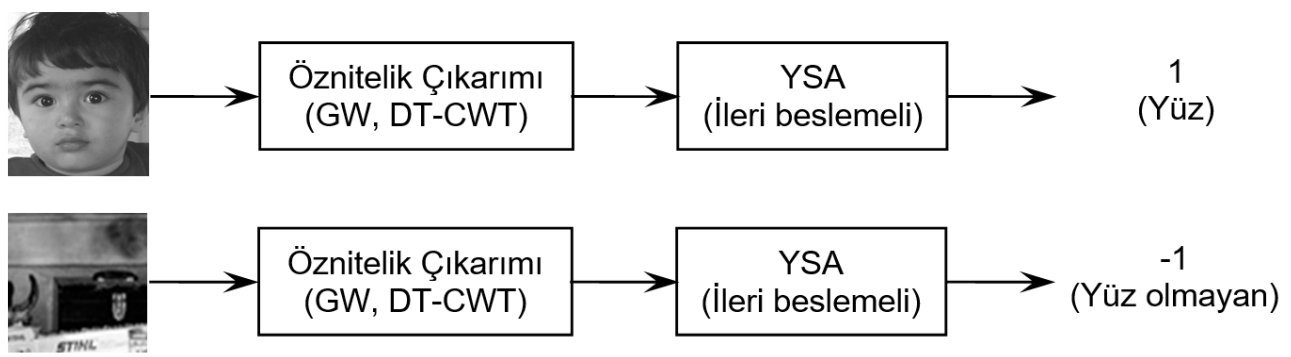

Şekil 7. Sinir ağının eğitimi

Figure 7. Training of the neural network

YSA'nın girişine 1000 pozitif örnek (yüz görüntüsü) ve 1000 negatif örnek (yüz olmayan) beslenmiştir. Yüz görüntülerinin hedef çıkış değeri "1", yüz olmayan görüntülerin hedef çıkış değeri "1"olarak belirlenmiştir. YSA, iterasyon sayısı 1000, ortalama kare hatası (MSE) $10^{-4}$ ve aktivasyon fonksiyonu olarak Sigmoid $F(n e t)=\frac{1}{(1+\exp (-n e t))}$ fonksiyonu kullanılmıştır. Giriş nöronlarının sayısı, kullanılan öznitelik çıkarım yöntemine bağlı olarak farklılık göstermektedir. Gabor Dalgacıklar için vektör uzunluğu 1860 iken, Çift Ağaç Dalgacıklar için 996'dır. Her iki yöntemde de saklı katmandaki nöronların sayısı 100'dür. Öğrenme oranının değeri 0.1'dir. Momentum sabiti 0.95 olarak kullanılmıştır. Birçok denemeden sonra seçilen bu parametre değerleri ile yüz algılama başarısı en yüksek orana ulaşmıştır. Şekil 8'de, kullanılan Yapay Sinir Ağı'nın yapısı görülmektedir. Buradaki $\mathrm{n}$ değeri, kullanılan öznitelik çıkarım yöntemine göre değişmektedir.

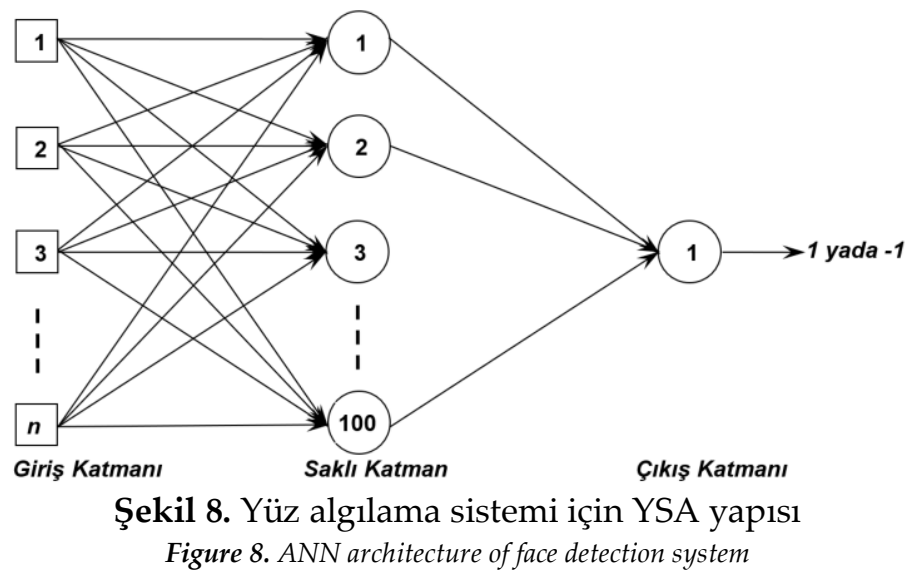

İterasyon sayısı en yüksek değere ulaştığında (1000) veya hedeflenen hata değerine ulaşıldığında $\left(10^{-4}\right)$, YSA eğitiminin bittiği kabul edilmektedir. Bundan sonra, katmanlar arasındaki ağırlıklar kaydedilmektedir. Bu aşamadan sonra sistem, test edilecek görüntü için hazırdır.

\section{Önişleme Basamağı (Preprocessing Step)}

Bu çalışmadaki öntarama işlemi (Telatar ve diğ., 2007)'ın çalışması örnek alınarak yapılmıştır. Yüz algılama sisteminin işlem yükünün ve buna bağlı olarak zamanının azaltılmasını hedefleyen bu yöntem, yüz olma olasılığının düşük olduğu alanların elenmesi esasına dayanmaktadır.

Genellikle yüz algılama algoritmalarında yüzün algılanması işlemi, test edilecek görüntünün alt bloklarının bir pencere kullanılarak taranması ile yapılmaktadır. Tarama işleminin süresi, tarama penceresinin boyutu ve görüntü boyutu ile doğru orantılı olarak değişmektedir. Görüntü taranırken, yüz olmayan bölgeler üzerinde harcanan zaman çok fazla olmaktadır. Ağaç, duvar, gökyüzü gibi arkaplan bölgelerinin, her blok içindeki piksel değerlerinin varyansı, daha küçük bir değere sahipken yüz olan bölgelerin varyans değeri daha büyüktür. Ortalama ve standart sapma değerleri kullanılarak, 
test görüntüsü, ya yüz- yüze benzeyen bölge ya da yüz olmayan bölge olarak sınıflandırılır. Bunun için, ortalama ve standart sapma değerleri her iki bölge için hesaplanmış ve bu değerlerin en küçük ve en büyük olanları eşik değer olarak kullanılmıştır.

Görüntüye öntarama yapmak için, öncelikle tarama penceresinin büyüklüğüne karar verilmiştir. Yatay ve dikey yönlerin her ikisi için de en büyük pencere boyutu 20 pikseldir. Telatar ve diğ. (2007) çalışmalarında pencere boyutunun azaltılmasına devam edilmesinin daha iyi bir sonuç vermediği ve bununla beraber işlem zamanında da artış olduğunu göstermektedir. Tarama penceresi, görüntünün bütün pikselleri üzerinden tek tek geçmektedir. Standart sapma ve varyans, pencerenin altındaki alan için hesaplanmaktadır. Eğer bu değerler eşitlik 2'de tanımlanmış eşik değerlerini geçerse, pencere alanının tam ortasındaki piksel değeri kalır. Aksi takdirde, yüz algılama işleminde o piksel yok sayılmaktadir.

$$
\left(\mu \geq U T h_{\mu}\right) \&\left(\mu \leq L T h_{\mu}\right) \&\left(\delta \leq U T h_{\delta}\right) \&\left(\delta \geq L T h_{\delta}\right)
$$

Yukarıdaki eşitlikte, $U T h_{\mu}$ ve $L T h_{\mu}$ iki boyutlu ortalama değerin sırasıyla üst ve alt eşik değerlerleridir. $U T h_{\delta}$ ve $L T h_{\delta}$ ise sapma değerinin sırasıyla üst ve alt eşik değerleridir. $\mu$ ve $\delta$ değerleri pencerenin altındaki alanın ortalama ve standart sapma değerleridir.

Uygulama zamanının biraz daha azaltılması amacıyla görüntünün kenarlarına yakın, boyutları $(10 \times 10)^{\prime} l u k$ bir bölge yok sayılmıştır. Çünkü burada yüz bulunma olasılığı düşüktür. Şekil 9'da öntarama ve kenar çıkarma işlemlerinin birçok yüz içeren bir görüntü üzerindeki uygulaması görülmektedir.

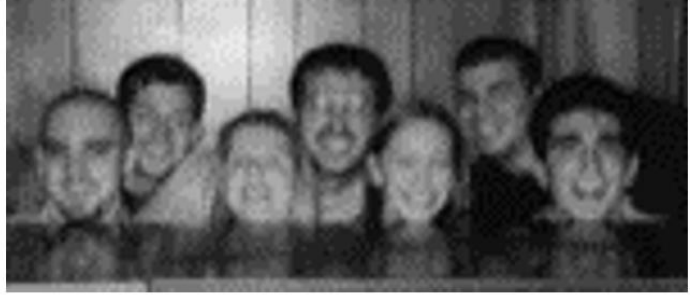

(a)

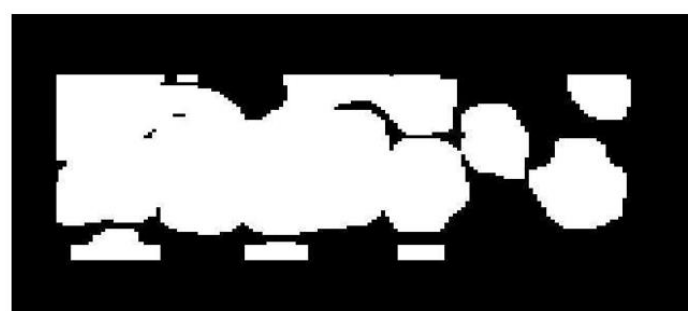

(b)

Şekil 9. Öntarama İşlemi (a) Yüz görüntüsü (b) Yüz olabilecek bölge

Figure 9. Preprocessing (a) Face image (b) Probable face region

\section{Histogram eşitleme (Histogram Equalization)}

Histogram eşitleme, görüntülerin kontrastını arttırmak amacıyla yapılan bir işlemdir. Genellikle kullanılan gri seviyeleri ifade eden sivri (peak) değerler, görüntünün histogramında eksen boyunca yayılmaktadır. Histogram eşitleme, yüz veritabanına ve yüz olmayan görüntülerin veritabanına uygulanmıştır. Bunun yanısıra, algılama işlemi boyunca her test görüntüsüne de histogram eşitleme uygulanmıştır.

\section{Yüz Algılama Algoritması (Face Detection Algorithm)}

Görüntülerde farklı boyutlarda birçok yüz olabilir. Kameraya olan uzaklıkları değişiklik gösterebilir. Tüm bu yüzlerin bütün ölçeklerde algılanabilmesi için, test görüntüsünün alt örnekleme yapılmış versiyonları oluşturulmaktadır. Bu görüntü versiyonları "görüntü piramidi" olarak adlandırılır. Yüz alg1lama algoritması, piramitteki her bir görüntüye uygulanmaktadır. Görüntünün bütün versiyonlarından gelen her bir sonuç, birbiriyle karşılaştırılarak hepsi tek bir sonuçta birleştirilmiştir. Bu işlem Ölçeklerarası Çözümleme olarak adlandırılır. Şekil 10' da farklı ölçeklerde algılanmış yüzler içeren bir görüntü piramidi örneği görülmektedir. Arkadaki yüz, ilk ölçekte iki kez, ikinci ölçekte bir kez olmak üzere üç kez algılanmıştır. Bu duruma üstüste algılama denir. 4. ölçekte öndeki yüz doğru algılanırken 3. ölçekte yanlış algılanmıştır. 


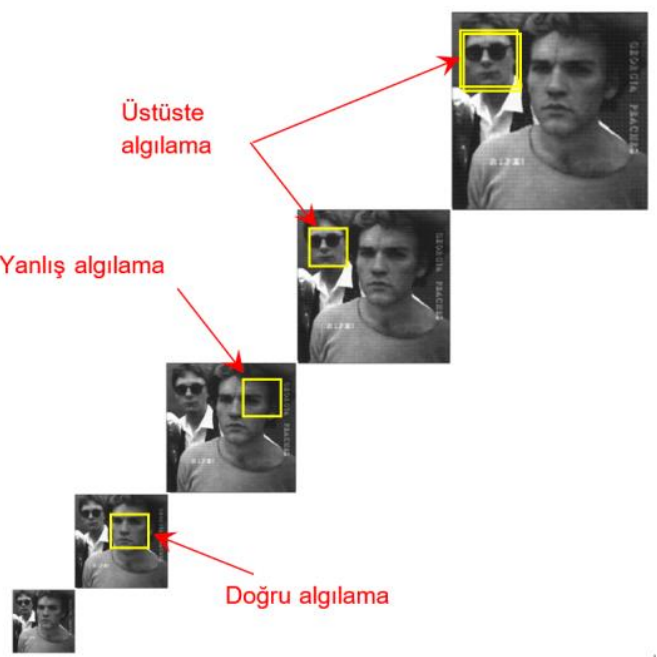

Şekil 10. Farklı ölçeklerde algılanmış yüzler içeren görüntü piramidi

Figure 10. Image pyramid with detected faces at different scales

Görüntü piramidi oluşturulduktan sonra, her ölçekteki görüntülere önişleme ve algılama işlemleri ayrı ayrı uygulanmaktadır. Öntarama işleminden sonra geriye kalan bölgeler, boyutu $20 \times 20$ olarak ayarlanmış alt pencere ile bir piksel aralıklarla taranmaktadır. Her alt pencereye histogram eşitleme yapılarak öznitelik çıkarımı için Gabor ve Çift Ağaç dalgacıkları uygulanmaktadır. Elde edilen görüntüler, bir vektör oluşturacak şekilde ardarda eklenerek YSA'nın girişine beslenmektedir. YSA, alt pencereyi, eğer yüz ise çıkış değeri "1", yüz değilse çıkış değeri "-1" olarak sınıflandırmaktadır. Alt pencerelerin ve görüntü piramidindeki tüm görüntülerin bu şekilde işlenmesinden sonra, ilgili ölçekteki yada ölçekler arasındaki üstüste gelmiş sonuçların ortadan kaldırılması için tüm bu sonuçlar karşılaştırılmış ve çözümleme (arbitration) yapılmıştır. Yukarıda detayları anlatılan yüz algılama sisteminin yapısı Şekil 11'de görülmektedir.

Yüz algılama sisteminin hata oranı, test veritabanındaki bütün görüntüler için hesaplanmıştır. Eşitlik 3'te görüldüğü gibi başarı oranı; doğru algılanan yüz sayısının görüntüdeki toplam yüz sayısına oranına eşittir.

$$
\text { başarı oranı }=\frac{\text { doğru algılanmış yüz sayıs1 }}{\text { toplam yüz sayısı }}
$$

Eşitlik 4'te görülen hata oranı, yanlış algılanmış yüz sayısının görüntüdeki toplam yüz sayısına oranı olarak hesaplanmıştır.

$$
\text { hata oranı }=\frac{\text { yanlış algılanmış yüz sayısı }}{\text { toplam yüz sayısı }}
$$




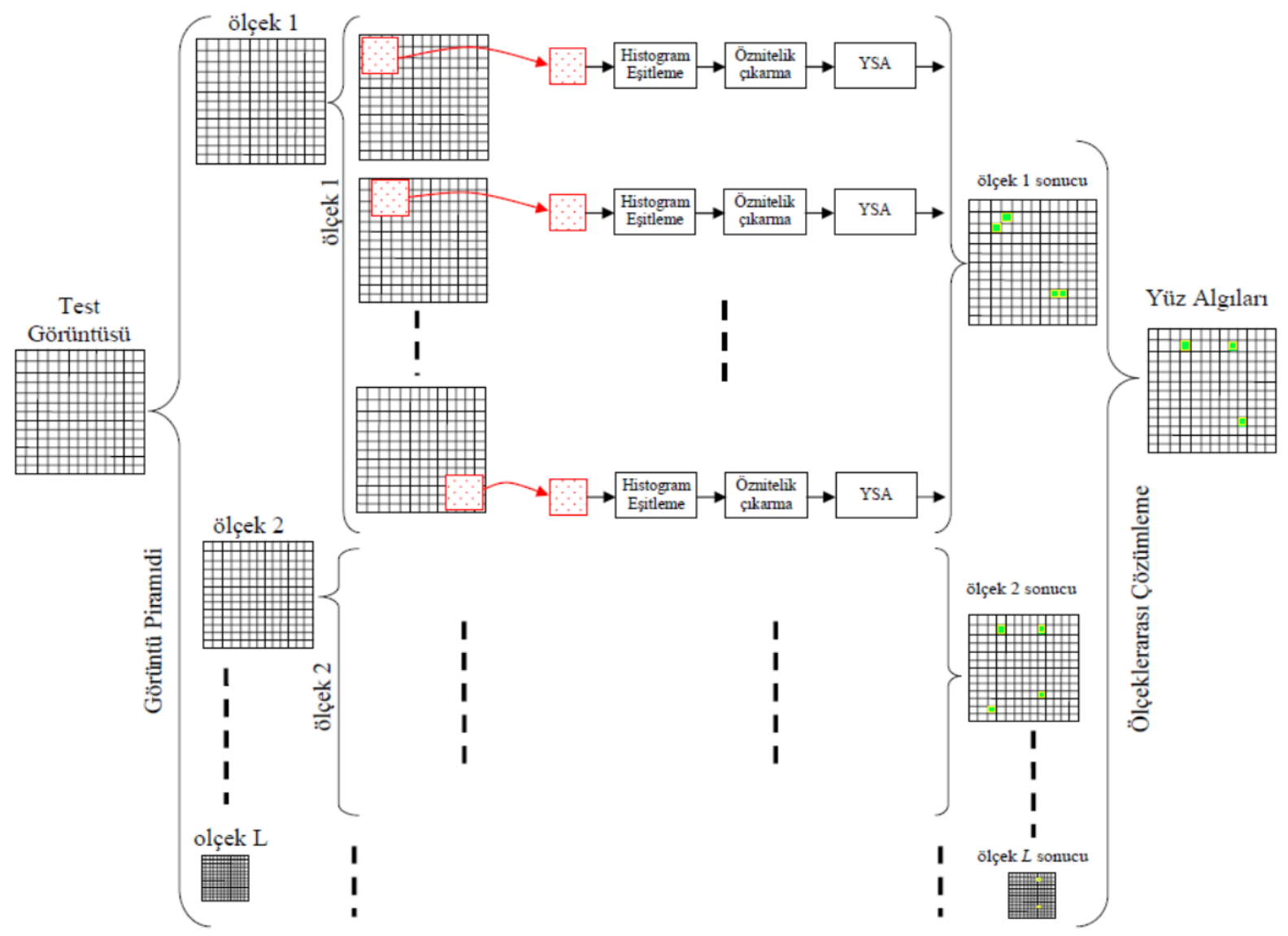

Şekil 11. Yüz algılama sisteminin yapısı

Figure 11. The structure of face detection system

Şekil 12'de ise örnek bir görüntü üzerinde sistemin çalışma şekli gösterilmektedir.

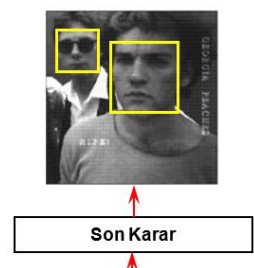

Öıçeklerarası Çözümleme

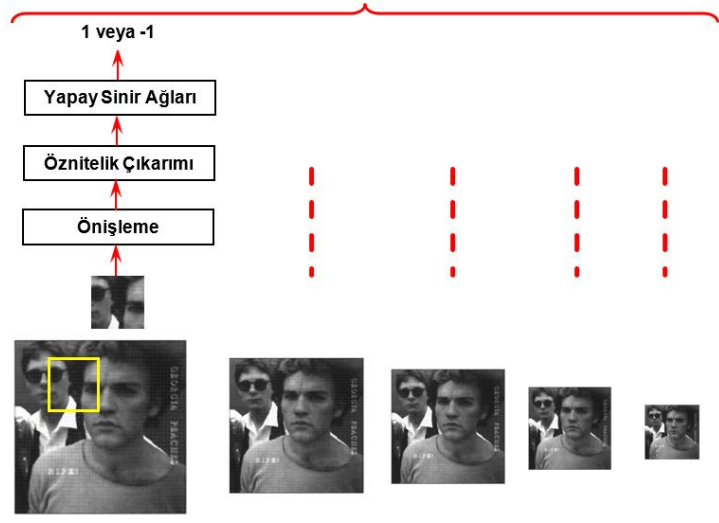

Şekil 12. Örnek görüntü için yüz algılama sisteminin çalışma mantığı Figure 12. Example on an image for the working mechanizm of face detection system 
Önerilen Sistemin Akış Diyagramı (Flow Diagram of the Proposed System)

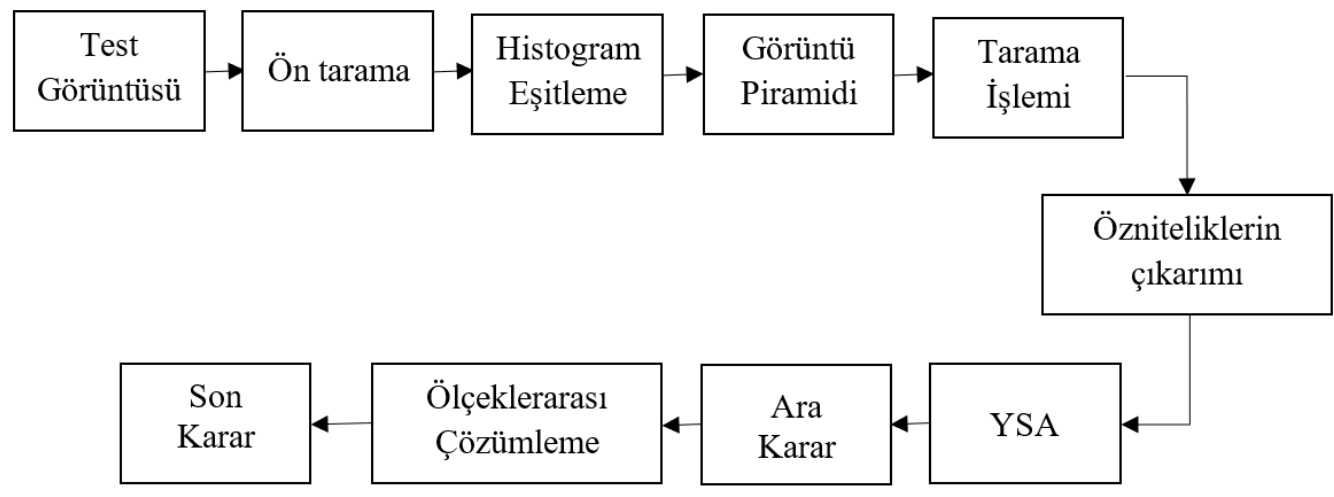

Şekil 13. Yüz algılama sisteminin akış diyagramı Figure 13. The flowchart of the face detection system

Şekil 13'te yüz algılama sisteminin akış diyagramı görülmektedir. Test görüntüsü üzerinde yüz olma olasılığının düşük olduğu alanların elenmesi amacıyla Öntarama işlemi yapılır. Daha sonra görüntü kontrastını arttırmak amacıyla Histogram Eşitleme işlemi yapılır. Görüntüde bulunan farklı boyutlardaki tüm yüzlerin doğru olarak algılanabilmesi için orijinal görüntü \%10 oranında azaltılarak Görüntü Piramidi oluşturulur ve bütün versiyonlar üzerinde 20×20 piksel büyüklüğündeki bir pencere ile Tarama işlemi gerçekleştirilir. Her tarama penceresine ayrı ayrı Gabor ve Çift-ağaç dalgacık dönüşümü uygulanarak Öznitelik Çıkarımı yapılır ve öznitelik vektörleri YSA girişine beslenir. YSA çıkışındaki değer eşik değerinin üstündeyse 'yüz', altındaysa 'yüz değil' olarak karar verilir. Bütün ölçeklerden gelen YSA çıkışları değerlendirilerek Son Karar belirlenir.

\section{SONUÇLARIN İRDELENMESİ (DISCUSSIONS)}

\section{Simulasyon Sonuçları (The Results of The Simulations)}

$\mathrm{Bu}$ bölümde, önerilen yüz algılama sisteminin performansını değerlendiren simülasyon sonuçlarından örnekler gösterilecektir. Genellikle yüz algılama amaçlı kullanılan MIT+CMU (Rowley et al. 1998, Sung and Poggio 1998) veritabanı ile kullanılarak elde edilen simülasyon sonuçları bir tablo içinde gösterilmiştir. Ayrıca, MIT+CMU veritabanındaki görüntüler farklı açılarla $\left(-10^{\circ},-5^{\circ}, 5^{\circ}\right.$, ve $\left.10^{\circ}\right)$ döndürülmüş ve sistem test edilmiştir. Daha sonra, yüz algılama sistemi FRAV2D (Serano et al.), BioID (Jesorsky et al. 2000) ve BANCA (Bailliére et al.) veritabanları kullanılarak da test edilmiştir.

Örnek sonuçlar Şekil 14'de görülmektedir. İlk olarak, Çift Ağaç Karmaşık Dalgacık Dönüşümü ve YSA kullanılarak sistem test edilmiştir. Elde edilen sonuçlar, Şekil 14(a)'da görülmektedir. Görüntüdeki 57 yüz içinden 54 yüz başarılı olarak algılanırken iki yanlış algı görülmektedir. Aynı görüntü için Gabor dalgacıklar ve YSA kullanılarak test yapılmıştır. Elde edilen sonuçlar Şekil 14(b)'de görülmektedir. Aynı şekilde 57 yüzden 54 yüz başarılı olarak algılanırken iki yanlış algı görülmektedir. Aşağıdaki sonuçlarda yanlış algılanan 2 görüntü ve 2 algılanamamış görüntünün Gabor dalgacıklar ve Çift Ağaç Karmaşık Dalgacık Dönüşümü kullanılarak yapılan testlerde aynı olmadığı görülmektedir. İki yaklaşımın sonuçlarının birleştirilmesiyle ortaya çıkan aynı pozisyon üzerindeki çoklu algılamanın ortadan kaldırılması, en büyük YSA çıkış değerine sahip pozisyonun seçilerek, diğerlerinin elenmesiyle gerçekleştirilir.

Şekil 14(c)'de iki yaklaşımın birleştirilmesi sonucunda elde edilen nihai sonuçlar görülmektedir. Resimlerin sağ alt köşesinde yer alan gösterim; toplam yüz/doğru alg1/yanlış alg1 olarak değerlendirilmelidir. 


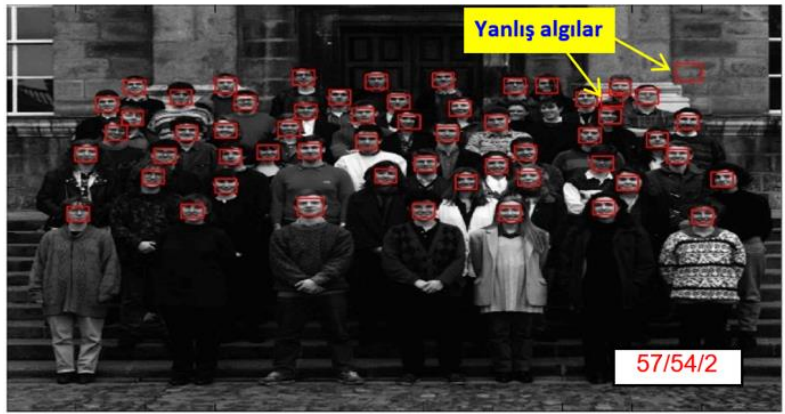

(a)

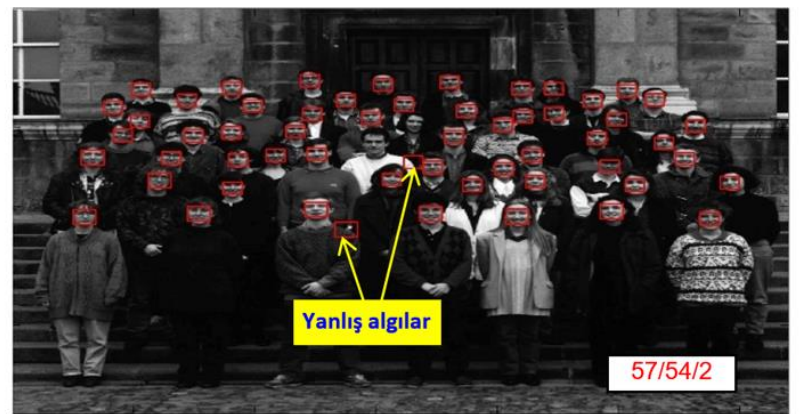

(b)

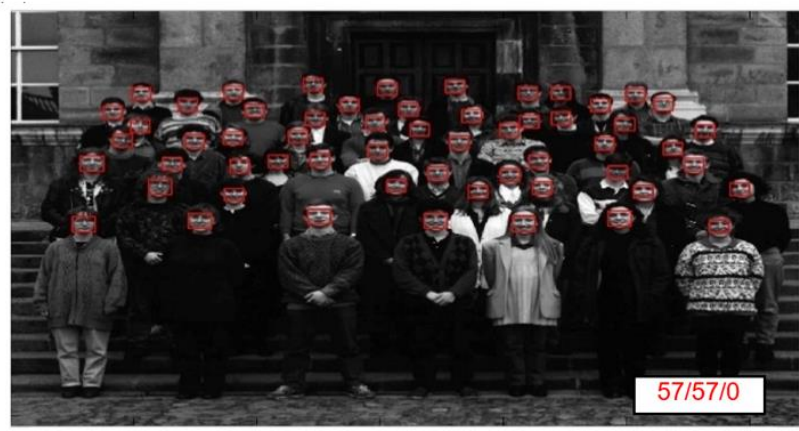

(c)

Şekil 14. Yüz algılama için örnek sonuçlar: (a) Çift ağaç+YSA, (b) Gabor+YSA ve (c) Gabor_Çift ağaç+YSA (toplam yüz/doğru alg1/yanlış alg1)

Figure 14. Example results for face detection: (a) Dual tree+ANN, (b) Gabor+ANN and (c) Gabor_Dual tree+ANN ( total faces / correct detections / false detections)

Şekil 14(c)'de doğru algılanan yüz sayısı artarken yanlış algıda azalma olmuştur. Bu sebeple yüz algılama sisteminin performans değerlendirmesine ait sonuçların gösterimine Gabor_Çift ağaç+YSA kullanılarak devam edilecektir . Şekil 15'de MIT+CMU veritabanından örnekler görülmektedir. Kırmızı kareler ile işaretlenmiş kısımlar doğru algılanan yüz bölgelerini ifade etmektedir.
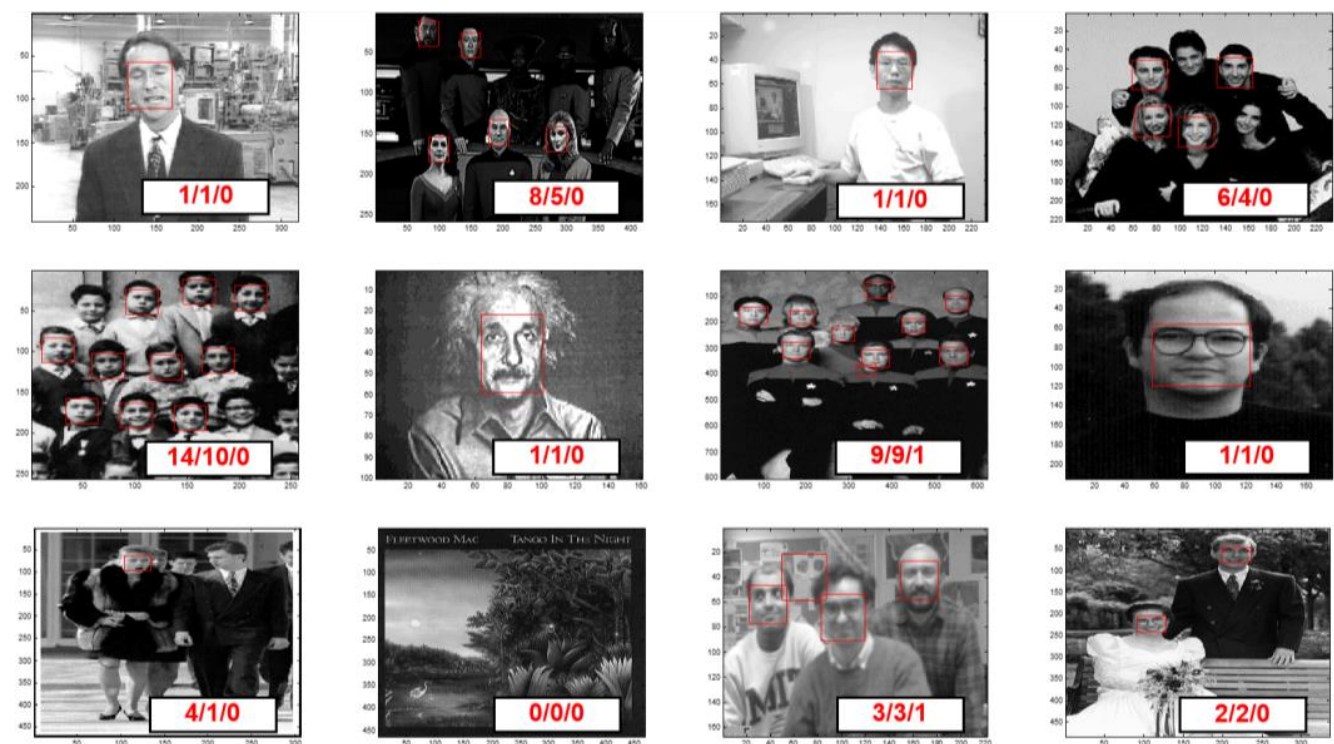

Şekil 15. MIT+CMU veritabanı kullanılarak yapılmış testler (toplam yüz/doğru alg1/yanlış algı) Figure 15. Tests using MIT + CMU database (total faces / correct detections / false detections) 
Çizelge 1'de MIT+CMU veritabanı kullanılarak Gabor Dalgacık Dönüşümü ve YSA, Çift Ağaç Dalgacık Dönüşümü ve YSA, ve her iki algoritmanın algı sonuçlarının birleştirilmesiyle oluşan Gabor_Çift Ağaç+YSA yaklaşımları ile tüm görüntüler üzerinde doğru ve yanlış algılar hesaplanmış, başarı yüzdeleri ile birlikte aşağıdaki tabloda gösterilmiştir. Gabor_Çift Ağaç+YSA algoritmasının doğru algılama performansı $\% 94.08$ ile en fazladır.

Çizelge 1. MIT+CMU veritabanı kullanılarak üç yaklaşım için yapılan peformans testi Table 1. Performance test for three approaches using MIT $+C M U$ database

\begin{tabular}{|l|c|c|c|}
\hline \multicolumn{1}{|c|}{ Algoritma } & Performans & AlgılananYüzler & Yanlıs Algılar \\
\hline Çift-ağaç+YSA & $\% 90.34$ & $458 / 507$ & 21 \\
\hline Gabor+YSA & $\% 87.38$ & $443 / 507$ & 28 \\
\hline Gabor_Çift-ağaç+YSA & $\% 94.08$ & $477 / 507$ & 16 \\
\hline
\end{tabular}

Bundan sonraki deneyler BANCA, FRAV2D ve BioID veritabanları üzerinde yapılmıştır. Şekil 16'da üç veritabanından elde edilen algılama sonuçları görülmektedir.

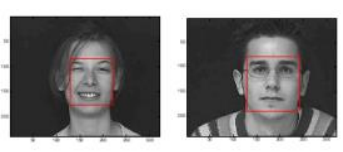

(a)
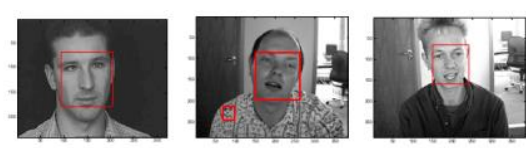

(b)
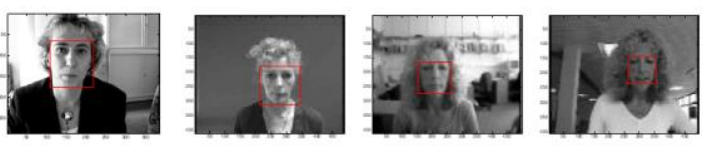

(c)

Şekil 16. (a)FRAV2D, (b) BioID ve (c)BANCA veritabanlarından algılama örnekleri Figure 16. Detection examples from (a) FRAV2D, (b) BioID and (c) BANCA databases

Çizelge 2'de üç farklı veritabanı kullanarak "birleşme" yaklaşımının performans ölçümüne ait örnekler görülmektedir. Toplam 11249 yüz içeren 11248 görüntü ile önerilen yaklaşım test edilmiştir. Bu yüzler içinden 11075 yüz, sadece 294 yanlış ile, algılanmıştır. Bu sonuçlara göre, önerilen yaklaşımın yüz algılama probleminin çözümünde etkili bir yöntem olduğu görülmektedir. FRAV2D veritabanında bulunan görüntülerdeki çoğu yüzün bazı kısımlarının kapanmış olmasından dolayı başarı yüzdesi diğerlerine göre düşük kalmıştır.

Çizelge 2. 3 farklı veritabanı kullanarak "birleşme" yaklaşımının performansı Table 2. Performance of the "combination" approach using 3 different databases

\begin{tabular}{|c|c|c|c|c|}
\hline Veritabanı & Toplam yüz sayısı & Performans & Algılanan yüzler & Yanlış algılar \\
\hline BioID & 1521 & $\% 99.41$ & $1512 / 1521$ & 49 \\
\hline FRAV2D & 3488 & $\% 97.33$ & $3395 / 3488$ & 87 \\
\hline BANCA & 6240 & $\% 98.85$ & $6168 / 6240$ & 158 \\
\hline
\end{tabular}

Diğer bir deneme ise, MIT+CMU veritabanındaki görüntülerin $-10^{\circ},-5^{\circ}, 5^{\circ}$ ve $10^{\circ}$ lik açlar ile döndürülerek, önerilen yüz algılama sisteminin peformansının test edilmesiyle yapılmıştır. Şekil $17^{\prime}$ de MIT+CMU veritabanındaki görüntülerin farklı açılar ile döndürüldükten sonraki algılama sonuçları görülmektedir. 


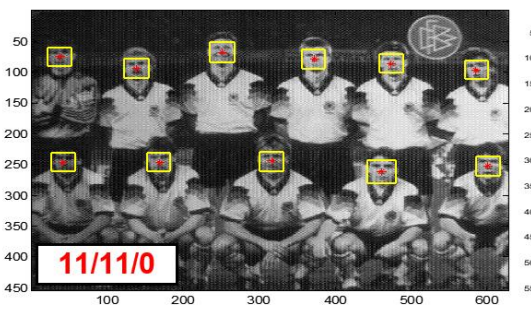

(a)

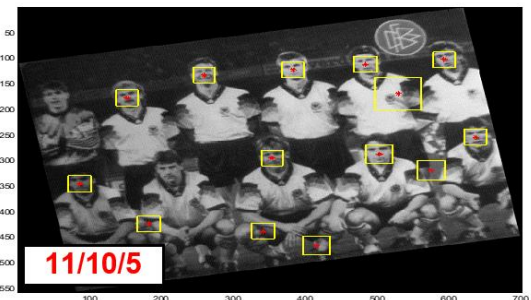

(b)

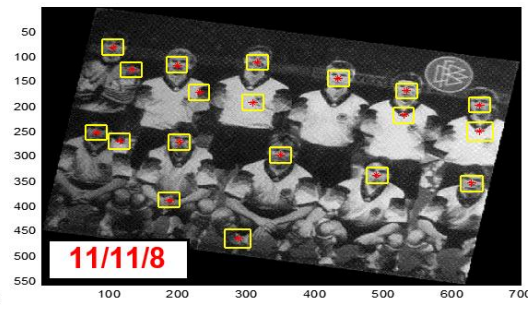

(c)

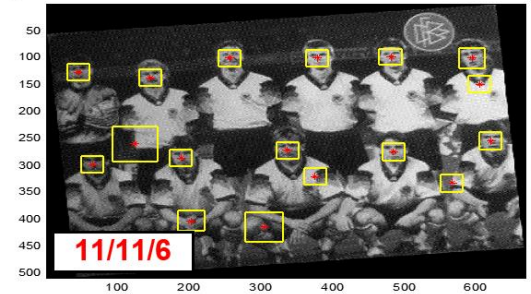

(d)

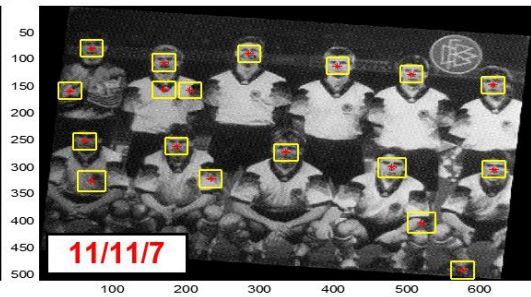

(e)

Şekil 17. Gabor-Çift ağaç+YSA ile farklı açlar: (a)orijinal, (b) $10^{\circ}$, (c) $-10^{\circ},(\mathrm{d}) 5^{\circ},(\mathrm{e})-5^{\circ}$ Figure 17. Gabor-Dual tree $+Y S A$ with different angles: (a) original, (b) $10^{\circ},($ c $)-10^{\circ},(d) 5^{\circ},($ e $)-5^{\circ}$

Çizelge 3. $\mathrm{MIT}+\mathrm{CMU}$ veritabanından farklı açılarla döndürülmüş görüntülerin yüz algılama performansları

Table 3. Face detection performance of images rotated in different angels from the MIT +CMU database

\begin{tabular}{|c|c|c|c|}
\hline Dönme AçıSı & Performans & Algılanan Yüzler & Yanlış Algılar \\
\hline-10 & 92.70 & $470 / 507$ & 119 \\
\hline-5 & 93.69 & $475 / 507$ & 87 \\
\hline 0 & 94.08 & $477 / 507$ & 16 \\
\hline 5 & 93.29 & $473 / 507$ & 49 \\
\hline 10 & 92.31 & $468 / 507$ & 55 \\
\hline
\end{tabular}

Sistemin eğitim basamağında kameraya doğru yan dönmüş yüzler bulunmamasına rağmen, sistemin performansı bu yüzler ile test edilmiştir. Çizelge 3'te farklı açılarla döndürülmüş görüntülerin yüz algılama performanslarının yüksek olduğu görülmektedir.

Rowley (1998), çalışmasında MIT+CMU veritabanında bulunan 23 görüntü ile sistemi test etmektedir. Çizelge 4'de önerilen Gabor-Çift ağaç+YSA yaklaşımı ve diğer bazı algoritmaların sonuçları ile yapılan karşılaştırma görülmektedir. Buna göre, önerilen algoritma \% 91.61 ile en başarılı yüz algılama oranını elde etmiştir.

Çizelge 4. MIT+CMU'dan 155 yüz içeren 23 görüntü ile önerilen sistemin diğer sistemler ile karşılaştırılması

Table 4. Comparison of the proposed system against other systems with 23 images containing 155 faces from MIT + CMU databse

\begin{tabular}{|c|c|c|c|}
\hline Algoritma & Performans & AlgılananYüzler & Yanlıs Algılar \\
\hline $\begin{array}{c}\text { Neural Networks [sistem 12] } \\
\text { (Rowley vd., 1998) }\end{array}$ & $\% 90.3$ & $140 / 155$ & 42 \\
\hline Perceptron (Sung, 1996) & $\% 76.8$ & $119 / 155$ & 5 \\
\hline MLP (Sung, 1996) & $\% 81.9$ & $127 / 155$ & 13 \\
\hline SVM (Osuna vd., 1997) & $\% 74.2$ & $116 / 155$ & 20 \\
\hline Gabor-Çift ağaç+YSA & $\% 91.61$ & $142 / 155$ & 9 \\
\hline
\end{tabular}




\section{SONUÇ (CONCLUSIONS)}

Görüntüler içinde yüzün algılanması problemi, "Yüz Tanıma" algoritmaları için önişleme aşamasında önemlidir. Bu çalışmada, yüz algılama için Gabor Dalgacık Dönüşümü ve Çift Ağaç Dalgacık Dönüşümünün kullanılması önerilmiştir.

Sistemin sınıflandırma basamağında ileri beslemeli sinir ağları kullanılmıştır. Sinir ağları geriye yayılım algoritması kullanılarak eğitilmiştir. Gabor öznitelik vektörlerinin uzunluğu 1864 olurken, Çift Ağaç öznitelik vektörlerinin uzunluğu 996'dır.

Yüz olma ihtimalinin yüksek olduğu bölgelerin çıkartılması ile gerçekleştirilen öntarama işlemi her test görüntüsüne uygulanmıştır. İşlem yapılacak alana karar verildikten sonra test görüntüsü $20 \times 20$ boyutundaki bir pencere ile taranarak öznitelik çıkarım birimine beslenmiştir. Öznitelik vektörleri sinir ağlarına uygulanır. Sinir ağının çıkış değeri, yüz'ün olması durumunda "1" olurken, yüz'ün olmaması durumunda "-1" olmaktadır. Test görüntüsüne birkaç kez altörnekleme işlemi yapılmış ve ölçeklendirilmiş her görüntüye aynı işlemler uygulanmıştır. Sonunda, tüm ölçeklerden gelen algı sonuçları birleştirilerek çoklu algılar ve yanlış algılar yok edilmiştir. Bu aşamada ya Gabor dalgacıklar yada Çift Ağaç dalgacıklar kullanılarak çıkarım yapılmıştır. Çıkarımdan sonra, test görüntüsü her iki sinir ağına ayrı olarak uygulanmıştır ve her iki ağ sonuçları birleştirilmiştir. Her iki ağdan elde edilen algılama sonuçlarının birleştirilmesiyle önerilen Gabor-Çift ağaç+YSA sisteminin doğru algılama performansının arttığı ve aynı zamanda yanlış algı sayısında azalma olduğu görülmektedir.

\section{KAYNAKLAR (REFERENCES)}

Acciani, G., Chiarantoni, E., Fornarelli, G. and Vergura, S. 2003. "A feature extraction unsupervised neural network for an environmental data set", Neural Networks, Cilt 16, no 3-4, ss. 427-436.

Eleyan, A., Ozkaramanli, H. and Demirel, H. 2009, "Dual-tree and single-tree complex wavelet transform based face recognition", SIU 2009, Side, Turkey, ss. 536-539.

Eleyan, A., Ozkaramanli, H. and Demirel, H. 2009, "Complex Wavelet Transform-Based Face Recognition“, EURASIP Journal on Advances in Signal Processing, Article ID 2008: 185281.

Eleyan, A., Demirel, H. 2007. "PCA \& LDA based Neural Networks for Human Face Recognition, in "Face Recognition ", edited by K. Delac and M. Grgic, Intech, ss.93-106.

Froba, B., Ernest, B. 2004. "Face detection with the modified census transform", Proc. IEEE International Conferance on Automatic Face and gesture Recognition, ss. 91-96.

Hongxia, J. 2007. "The application of neuro-FDT in urban short-term traffic flow prediction", 3rd International Conference on Natural Computation, China, ss. 499-503.

Huang, L.L, Shimizu, A., Kobatake, H., 2005, "Robust face detection using Gabor filter features", Pattern Recognition Letters, Cilt 26, Say1 11, ss. 1641-1649.

Karahan M., 2015, “Turizm talebinin yapay sinir ağalari yöntemiyle tahmin edilmesi, Süleyman Demirel Üniversitesi İktisadi ve İdari Bilimler Fakültesi Dergisi Y.2015, Cilt 20, Sayı 2, ss.195-209.

Kim, J.K., Kang, S., 2017, “Neural network-based coronary heart disease risk prediction using feature correlation analysis. Journal of Healthcare Engineering. vol. 2017, Article ID 2780501.

Kingsbury, N. G., 2003, “Design of Q-Shift Complex Wavelet for Image Processing Using Frequency Domain Energy Minimization", Proceedings of IEEE International Conference on Image Processing (ICIP '03), Cilt 1, ss. 1013-1016.

Lin, W.H., Wang, P., Tsai, C.F. 2016, “Face recognition using support vector model classifier for user authentication", Electronic Commerce Research and Applications Cilt18, ss. 71-82.

Liu, C. 2003, "A bayesian discriminating features method for face detection", IEEE IEEE Transaction Pattern Analysis and Machine Intelligence, Cilt 25, Sayı 6. ss. 725-740.

Liu, C. and Wechsler, H. 2003, "Independent component analysis of gabor features for face recognition", IEEE Transaction on Neural Networks, Cilt 14, Sayı 4, ss. 919-928.

Nanni, L. and Lumini, A. 2007, "Multi-expert approach for wavelet-based face detection", Pattern Recognition Letters, Cilt 28, Sayı 12, ss. 1541-1547. 
Oh, B.S., Oh, K., Teoh, A.B.J., Lin, Z., Toh, K.A., 2017, “A Gabor-based network for heterogeneous face recognition", Neurocomputing, Cilt 261, ss. 253-265.

Ratsch, M., Romdhani, S. and Vetter, T. 2004, "Efficient face detection by a cascaded support vector machine using haar-like features. Proc. 26th Pattern Recognition Symposium, Tübingen, ss. 62 70.

Rowley, H., Baluja, S. and Kanade, T. 1998, “Neural network-based face detection”, IEEE Pattern Analysis Machine Intelligent Transaction, Cilt 20, ss. 22-38.

Schneiderman, H. and Kanade, T. 2000, "A statistical method for 3D object detection applied to faces and cars", Proc. IEEE Conf. Computer Vision and Pattern Recognition, Cilt 1, ss. 746-751.

Shah, P. M. 2012, "Face detection from images using support vector machine", Yüksek lisans tezi. 321. San José State University.

Sharma, M., Verma, P., Mathew, L., 2016, "Design an intelligent controller for a process control system", International Conference on Innovation and Challenges in Cyber Security (ICICCSINBUSH), Noida, ss. 217-223.

Sung, K. K., Poggio, T. 1998, "Example-based learning for view-based human face detection," IEEE Transactions on Pattern Analysis and Machine Intelligence, Cilt 20, Sayı 1, ss. 39-51.

Telatar, Z., Sazlı, M.H., Muhammad I., 2007, "Neural network based face detection from pre-scanned and row-column decomposed average face image", ACIVS 2007, LNCS 4678, ss. 297-309.

Türkeç, M.B. 2007, Bayes sınıflandırıcı kullanarak yüz sezimi. Yüksek lisans tezi, Hacettepe üniversitesi, 91 s., Ankara.

Tsai, C.C., Cheng, W.C., Taur, J.S., Tao, C.W. 2006, "Face detection using eigenfaces ad neural network", Proc. IEEE Int'l Conf. on Systems, Man, Cybernetics, ss. 4343-4347.

Turk, M., Pentland, A. 1991. Eigenfaces for Recognition. Journal of Cognitive Neuroscience, Cilt 3, Sayı 1, ss. 71-86.

Yang, G., Huang, T. S. 1994, "Human face detection in complex background", Pattern Recognition, Cilt 27, Sayı 1, ss. 53-63. 